\title{
ASSESSING FINANCIAL RISK IN PUBLIC-PRIVATE PARTNERSHIP FINANCING FOR ROAD CONSTRUCTION PROJECTS IN IRAN USING UNCERTAINTY CONDITIONS APPROACH
}

\author{
M. Jaafarian ${ }^{\text {a }}$, A. Ardeshir ${ }^{* b}$, A. Firozi Boyaghchi ${ }^{\text {c }}$ \\ ${ }^{\text {a }}$ Islamic Azad University, Branch of Science and Research of Tehran, Tehran, Iran, Doctoral School, \\ e-mail: mohamadreza.jafarian.ilam@gmail.com \\ b* Amirkabir Universiy, Tehran, Iran, e-mail: ardeshir@aut.ac.ir \\ c Islamic Azad University, Branch of Science and Research of Tehran, Iran, e-mail: affirozi@yahoo.com
}

Received: 27.04.2020 / Accepted: 18.05.2020/ Revised: 19.08.2020 / Available online: 15.12.020

DOI: 10.2478/jaes-2020-0021

KEY WORDS: Financial Risk, Public-Private Partnership, Road Construction Projects, Uncertainty, Grounded Theory.

\begin{abstract}
:
Private section investment in the construction of transportation infrastructure, one of the most important of which is freeway projects, has been extensively used in developing countries in recent decades. However, in many cases due to the lack of necessary investigations and studies, the criteria have not been properly identified and, as a result, the proper way of participating in large-scale transport projects has resulted in numerous problems and, in some cases, project failure. However, choosing a private-public partnership will have a major impact on the success of freeway construction. However, due to the current conditions of the country's economy, these projects are following with some risks. Therefore, in this study, the financial risk assessment of "public-private partnership" financing for road construction projects in Iran was investigated using the uncertainty approach and the BAS method. The research population of this study consisted of 23 researchers and experts with Ph.D. degree in finance with minimum degree of associate degree and experience of research and financial consulting in investment firms. According to the results, the lack of stability in planning and implementation of government programs and political risks, increases the risk of road construction projects and, in this regard, controlling the price fluctuations and bank financing of road construction projects can reduce the risk of these projects.
\end{abstract}

\section{INTRODUCTION}

In recent years, due to the population growth and economic development of different countries, there is a strong need for infrastructure in many countries (World, 2008), while government funds devoted to develop the infrastructure are limit and non-optimal (Jin, 2011). However, it is perceived that it is impossible to reach the boundaries of development without the dynamic role of the government. Accordingly, the presence of the government is essential both in determining the current rules and in overseeing the interpretation and implementation of decision-making rules, but the important point is how it is represented in economic, civil and industrial matters (Yescombe, 2011). For this reason, governments have tried to find a new solution to these shortcomings by employing the private sector and activating it in infrastructure projects. One of the solutions proposed is to implement the project using publicprivate partnership contracts (Noorzai, Jafari, Golabchi, \& Hamedi, 2016). Public-Private Partnerships (PPTs) are a longterm contract between a public sector organization and a private representative, whereby resources and project risks are shared between the parties to the contract, with the aim of developing or renovating public facilities (Abadi, Behnaba, \& Akbari, 2014).
Public-private partnerships in developed countries have been widely used to implement various projects such as road construction, health and education (Heravi \& Alkass, 2008).

Recently, in developing countries, due to the lack of financial resources to build and develop infrastructures, there is a great incentive to apply PPP contracts (Abadi, et al., 2014). Such partnerships, by type of partnership, specify precisely the scope of government and private sector involvement, with the state being maintained as a policy-making and directing authority and the private sector acting as the executive arm. Experience from different countries shows that the government is confronted with some problems due to factors such as limited funding and funding to finance large-scale projects; also the high demand for investment in these projects, encourage governments to attract active private sector participation (Heybati, Rahnama, Nikoumaram, \& Ahmadi, 2009). Therefore, in recent years, the use of public-private partnerships has become more emphasized in light of the financial constraints on the country's annual budgets and the potential financial risks, especially in the face of economic problems and the specific complexities of uncertainty.

* Corresponding author: Ardeshir A., Member faculty and professor, Amirkabir Universiy, Tehran,

Iran, e-mail: ardeshir@ aut.ac.ir. 
On the other hand, a development project such as the road project from the planning stage to the construction and completion phase of the project, and especially at the construction stage, faces numerous risks, which can include issues such as the difficulty of land acquisition and design changes by necessary external factors.

Since these factors and risks can offset the time and cost of compensation, it is essential to properly identify and manage risks. This is especially important for developing countries where risk-related data collection is costly and time consuming.

In Iran, due to the unfavorable conditions of air and rail transport, special attention is paid to the development of land transport and proper planning has been carried out by the government. Given the profitability of freeway projects in Iran, these projects are the most appropriate way to participate. The most important problem for developing freeway projects in Iran is financing these infrastructure projects. With the emphasis on the Fourth and Fifth Development Law of the country on the use of the private sector in transportation projects, and in particular freeway projects, the government has attempted to implement these projects through public-private partnership practices. However, while the long-term PPP, the need for private sector project profitability, and the ongoing relationship between government agencies and the private sector has made these contracts highly sensitive to the financing method and technical features of the project, it requires extensive research and study. Because the specific structure of state-owned road construction projects due to public sector rule also adds to the complexities of using private sector participation in these projects. Freelance road projects have certain characteristics such as the multitude of economic and social parameters affecting travel attraction and production, the project's profitability, project demand and project cost estimates and accurate projections, high technical, operational and financial need compared to other projects. There are other transport projects that require the skill of the designer and builder as well as the full transfer of design and construction risks to the government. Therefore, due to low skills and experience of the private sector and unstable conditions, poor environmental conditions, etc. in Iran, identifying the appropriate method of financing these projects can be very effective in achieving success in these projects (Golabchi, 2015). However, in our country, less attention has been paid to the study of different aspects of PPP use than other countries and even other developing countries. However, experiences learned from projects done around the world can help identify effective benchmarks and choose the right contracting method to avoid repeating previous mistakes in future projects. In this regard, Rasouli et al. (2018) have identified, ranked and assigned the critical risks of public-private partnership by using Delphi techniques in the context of a resilient economy in the Guilan province water and wastewater industry (Rasouli, Khodiaryar, \& Bani Mahd, 2018). In this study, using Delphi questionnaire and technique, it was concluded that there is a significant relationship between high importance risks in different stages of public-private partnership of Guilan water and wastewater industry.

In a study, Norouzi et al. (2015) examined the critical success factors in the implementation of public-private partnership projects in the field of energy of the Islamic Republic of Iran in the electricity industry (Norouzi, Ashari, \& Beladian, 2015). The data were collected by questionnaire and the TOPSIS method was used to rank factors. According to the research findings, socio-political factors are the most important identified factors and economic-financial and infrastructure factors are ranked next. Sadeghi Shahedani et al. (2011) have prioritized a research on the barriers to the development of public-private partnerships in the Iranian transportation sector using MCDM methods and the results indicate that factors related to capital market constraints and access to finance are the most important identified obstacles (Sadeghi, Shahbazi, \& Bigdeli, 2012). Among the abroad studies conducted in this field, the study of $\mathrm{Hu}$ and Han (2018) can be mentioned. In this study the monetary value of China's highway projects was evaluated under public-private partnership contracts; according the findings, three main related issues were identified include reduce the risk of social instability, reduce government spending following a reasonable range of low discount rates, and increase freight costs through substitution.

Brzezinski et al. (2018), in a study titled, evaluating the effectiveness of public-private partnership projects in Russia, suggests a method for ranking countries that are likely to succeed in implementing public-private partnerships based on environmental quality; in this study, organizational factors, project implementation experience, government preparedness, private organizations and community are considered as research indicators (Berezin, Sergi, \& Gorodnova, 2018). Based on these indicators, and given what has been addressed in this study, public-private participation opportunities are expected to increase. In Yosama et al.'s (2015) study, which is a risk allocation model for infrastructure projects in Yemen, 30 risks were rated using the Delphi technique. The results show that the understanding and application of this model is easy for contracting parties and helps decision makers to make the best choice among different projects based on risk factors in the bid and offer phase. The risk allocation model enables risk management.

Given what has been said, a more comprehensive study and more efficient management of road construction projects seems critical. Therefore, reviewing and selecting the appropriate method of financing Iranian freeway projects is very important due to the challenges involved in the success of these projects. And it will have significant repercussions for the Iranian economy. Therefore, this study focuses on the assessing financial risk in public-private partnership financing for road construction projects "in Iran with uncertainty approach.

\subsection{Theoretical Background: Public-Private Partnership}

There is not any general and well-known definition for publicprivate partnership, some believe, that the partnership is a new political tool for the government to replace traditional methods of public service contracts in a competitive environment, and others such as Linder considered it as a type of organized procedure for the participation of private organizations in the economy to provide public services (Linder, 1999). However, the principle of public-private partnerships, as discussed above, is based on incorporating the private sector as an independent entity in economic activity. Another group of scholars such as Grimsey and Lewis define public-private partnerships based on their duration and the context in which they are used; for example, noted cooperation can be considered as some orders and agreements in which, private sector committed to build or manage infrastructures and services in ling-term contracts 
(Grimsey \& Lewis, 2007). Public-private partnerships are a new way to launch infrastructure projects such as tunnel construction, highway construction, construction of the port and etc (Savas \& Savas, 2000). Other definitions refer to the division of labor involved in these contracts; for example, Standard \& Poor's public-private partnerships provide any medium- to long-term relationship between sectors. It defines the private and the public, which includes the division of risk and returns, skills, expertise, and multidisciplinary finance to achieve the desired policies. Accordingly, public-private partnerships can be considered a range of contracts in which both the public and private sectors have responsibilities and commitments for the implementation of the projects concerned, but the extent of these responsibilities and obligations in each of these Contracts are different. In some contracts, the role of the government is significant, while in others the role of the private sector is more significant.

Some researchers consider this type of partnership as the best alternative to traditional methods of the past. For example, Laoser points out that public-private partnerships for a variety of reasons, such as the provision of services with less uncertainty, the use of better technology and project-based knowledge, the achievement of contractual objectives, the benefit of long-term contracts, and the appropriate risk allocation, Outperform traditional methods of public service provision (Lawther, 2005). Others also considered the public reform movement as the "new public management" as one of the theoretical areas of the "partnership" contracts (Yescombe, 2011). Overall, it should be noted that public-private partnerships is different than privatization because of numerous reasons; for example in joint venture schemes, ownership of physical assets is usually owned (or transferred) to the public sector, but in the program of privatization, these assets are related to private section.

\section{METHODOLOGY AND RESEARCH PROCESS}

Because of its extension, the research was carried out in five steps, and each had its own research method (Table 1).

\begin{tabular}{|c|l|l|}
\hline Step & \multicolumn{1}{|c|}{ Method } & \multicolumn{1}{|c|}{ Title } \\
\hline First & $\begin{array}{l}\text { Librarian study } \\
\text { Semi-structured } \\
\text { Interview }\end{array}$ & Data Collection \\
\hline Second & & $\begin{array}{l}\text { Open coding and extracting } \\
\text { financial risk concepts in } \\
\text { financing approach }\end{array}$ \\
Third & \multirow{5}{*}{ Grounded } & $\begin{array}{l}\text { Axial coding and extracting } \\
\text { financial risk concepts in } \\
\text { financiang approach }\end{array}$ \\
\cline { 3 - 3 } Fourth & $\begin{array}{l}\text { Selective coding and extracting } \\
\text { financial risk concepts in } \\
\text { financiang approach }\end{array}$ \\
\hline Fifth & $\begin{array}{l}\text { Conceptual } \\
\text { Mapping }\end{array}$ & $\begin{array}{l}\text { Codifying a comprehensive } \\
\text { credit risk management model }\end{array}$ \\
\hline
\end{tabular}

Table 1. Research methodology and process

At first, financial risk statements were collected by library risk analysis and semi-structured interviews and then the collected data were codified in three steps by Grand Data Theory and then key concepts, components and categories of financial risk were extracted. Interviewees in this study are researchers and experts in financial risk with a Ph.D. degree in finance and with a minimum degree of associate degree and have had an article, research project or book. These experts also have a track record of financial consulting with investment firms.

Grounded theory is an inductive and exploratory research method that allows researchers in a variety of subject areas to develop their own theory rather than relying on pre-defined theories (Salsali, Fakhr Movahedi, \& Cheraghi, 2007). In grounded theory methodology, the theory is discovered or produced on the basis of existing facts and realities, by systematically collecting data and taking into account all aspects relevant to the research subject. The collected data are investigated and analyzed until it reaches theory (Corbin \& Strauss, 2014).

After extracting the components and categories, using a cognitive mapping approach, a conceptual model was developed.

In order to design the conceptual framework of the comprehensive financial risk model in the cognitive mapping framework, experts were referred in two stages. In the first stage, the results of the library study and semi-structured interview were presented to the experts and asked to determine the factors affecting the financial risk. Responses collected from each expert were coded and aggregated by the researcher at this stage through the Grand Theory and prepared in the form of a final cognitive mapping. In the second stage, the cumulative cognitive mapping from the first stage was re-presented to the experts and asked to confirm the categories and components identified in the previous step. Thus, a comprehensive financial risk model is developed in the financing method, including categories and components of financial risk. As stated above, participants were selected from among experts with a $\mathrm{PhD}$ in finance, as well as researchers and investigators who have had an article, research project, or book and have had financial advisory background in investment companies, based on the following criteria:

1.The Vital Role: their effective role in the area of financial risk.

2. Identified by Others: In the area of financial risk, they have been endorsed by the experts in the field.

3. Theoretical understanding of the subject: Have sufficient mastery of academic risk and specialized literature on financial risk.

4. Diversity: They have had a history of investing in companies.

5. Finally, the desire for participation: The interest and the trustiness have been considered as main factors.

Demographic characters of participants were indicated in Table 2.

\begin{tabular}{|c|c|c|c|}
\hline \multirow{2}{*}{\multicolumn{2}{|c|}{ Character }} & \multicolumn{2}{|c|}{ Frequency } \\
\hline & & \multirow{2}{*}{$\begin{array}{l}\text { Number } \\
23\end{array}$} & \multirow{2}{*}{$\begin{array}{l}\text { Percent } \\
100\end{array}$} \\
\hline $\begin{array}{l}\text { Degree of } \\
\text { Education }\end{array}$ & Ph.D & & \\
\hline Job & $\begin{array}{l}\text { Member Faculty and } \\
\text { Financial Conselor }\end{array}$ & 23 & 100 \\
\hline \multirow{2}{*}{$\begin{array}{l}\text { Educational } \\
\text { Course }\end{array}$} & Accounting & 9 & $39 / 11$ \\
\hline & Financial Management & 14 & $60 / 89$ \\
\hline \multirow{2}{*}{$\begin{array}{l}\text { Scientific } \\
\text { Rank }\end{array}$} & Professor Assistant & 18 & $78 / 26$ \\
\hline & Professor & 5 & $21 / 73$ \\
\hline
\end{tabular}

Table 2. Demographic characters of participants 


\subsection{Data Analysis}

The data of this study were analyzed based on Strauss and Corbin's (2011) guidelines on road construction projects in Iran. This method consists of three main steps: open coding, axial coding, and selective coding. Finally, the qualitative model of research is expressed.

A) Open coding: Open coding is the first step in data analysis and coding. During the open coding phase, the data from the interviews were carefully reviewed; the main categories and sub-categories identified, and the sub-categories (subcategories) were identified. During these analyzes, the proposed analytical techniques of Strauss and Corbin (2011) were applied. The main units of analysis for open coding were concepts. Interview transcripts were regularly reviewed to find out the main categories, subjects, subcategories. During the coding process, 51 open codes, 33 concepts, and 16 categories were extracted and their characteristics related to Iranian road projects were identified.

B) Axial coding: In axial coding, concepts are based on commonalities or semantics. In other words, the primary codes and categories created in open coding are compared, and by integrating code that is conceptually similar, the related categories are centered on one another. In fact, at this stage, the dimensions of the coding paradigm are formed and include six categories include, axial categories, causal conditions, confounding conditions, governing context conditions, strategies and outcomes (Table 3). So, in the study, analysing data obtained by Interview carried out based on coding paradigm.

\begin{tabular}{|c|c|c|}
\hline Selective Coding & Axial Coding & Open Coding \\
\hline \multirow[t]{2}{*}{ Current conditions } & Liquidity Risk & $\begin{array}{l}\text { 1. If you finance the project in the form of buyer bonds, you will be exposed to } \\
\text { liquidity risk. } \\
\text { 2.Liquidity risk in these projects should be taken seriously. } \\
\text { 3. The faster the asset is traded; the less liquidity risk is provided. } \\
\text { 4. Investors look at liquidity in the sense that they can buy and sell assets. }\end{array}$ \\
\hline & Market Risk & $\begin{array}{l}\text { 1. Investors in these projects face direct market risk. } \\
\text { 2.Market risk is caused by changes in the price of financial instruments. } \\
\text { 3. Financial risk includes market risk. } \\
\text { 4. Direct market risk is caused by changes in stock prices and interest rates. }\end{array}$ \\
\hline \multirow[t]{3}{*}{ Pivotal Category } & Inflation Risk & $\begin{array}{l}\text { 1.The inflation risk is the most important financial risk. } \\
\text { 2.Inflation risk should be taken seriously by the investors of these projects. } \\
\text { 3. Inflation Risk is one of the most important issues of financial risk assessment and it } \\
\text { affects the entire Iranian industry. } \\
\text { 4. Inflation risk can affect the expected rate of return on these projects. } \\
\text { 5. The contractors of these projects are undoubtedly at risk and inflation rate } \\
\text { fluctuations. } \\
\text { 6. Inflation Risk can affect the expected rate of return first and then the financial risk. }\end{array}$ \\
\hline & Credit Risk & $\begin{array}{l}\text { 1.Credit risk is a type of financial risk that cannot be saw by investors of these } \\
\text { projects. } \\
\text { 2. Credit risk is in the form of bonds. } \\
\text { 3. Credit risk is based on the fact that the contracting party does not want or cannot } \\
\text { fulfill its obligations. } \\
\text { 4. Credit risk loss may occur prior to the actual default of the contracting party. } \\
\text { 5. Credit risk is one of the most important risk generating factors in banks and } \\
\text { financial companies. } \\
\text { 6. Projects are themselves affected by credit risk. }\end{array}$ \\
\hline & Interest Rate Risk & $\begin{array}{l}\text { 1- Interest rate risk is the root of financial risk. } \\
\text { 2- Interest rate risk is one of the financial risk priorities of these projects. } \\
\text { 3. Interest rate risk is the risk that investors in these projects face. } \\
\text { 4- Interest rate risk leads to inflation and financial risk. }\end{array}$ \\
\hline \multirow[t]{3}{*}{ Casual conditions } & $\begin{array}{l}\text { State stability in } \\
\text { planning and } \\
\text { implementation }\end{array}$ & $\begin{array}{l}\text { 1- Failure by the government to fulfil its obligations. } \\
\text { 2- High diversity of directives issued by the Iranian government. } \\
\text { 3. The ability to repay a project for a project in which the Iranian government plays an } \\
\text { important role. }\end{array}$ \\
\hline & $\begin{array}{l}\text { The nature of the } \\
\text { Iranian capital } \\
\text { market }\end{array}$ & $\begin{array}{l}\text { 1- Understand the main nature of the market in terms of investment. } \\
\text { 2. Selecting the appropriate portfolio according to the market conditions to compensate } \\
\text { for the loss in one share by another stock. } \\
\text { 3. Impact of investment projects according to the type of capital market on financial risk. }\end{array}$ \\
\hline & Political Risk & $\begin{array}{l}\text { 1. Political and commercial risks affect the financial risk of projects. } \\
\text { 2. One of the factors that threatens companies and investors in these projects and } \\
\text { increases financial risk is political risk. } \\
\text { 3. Political risk is not financial risk per se, but because it affects interest rates it can } \\
\text { initiate financial risk. } \\
\text { 4- Political risk has always affected interest rates in our country. } \\
\text { 5. If we consider political risk as a tree, the interest rate, exchange rate, inflation risks } \\
\text { are considered as the foliage of that tree (political risk). }\end{array}$ \\
\hline Strategy & Financing & 1. Bank-centric project financing. \\
\hline
\end{tabular}




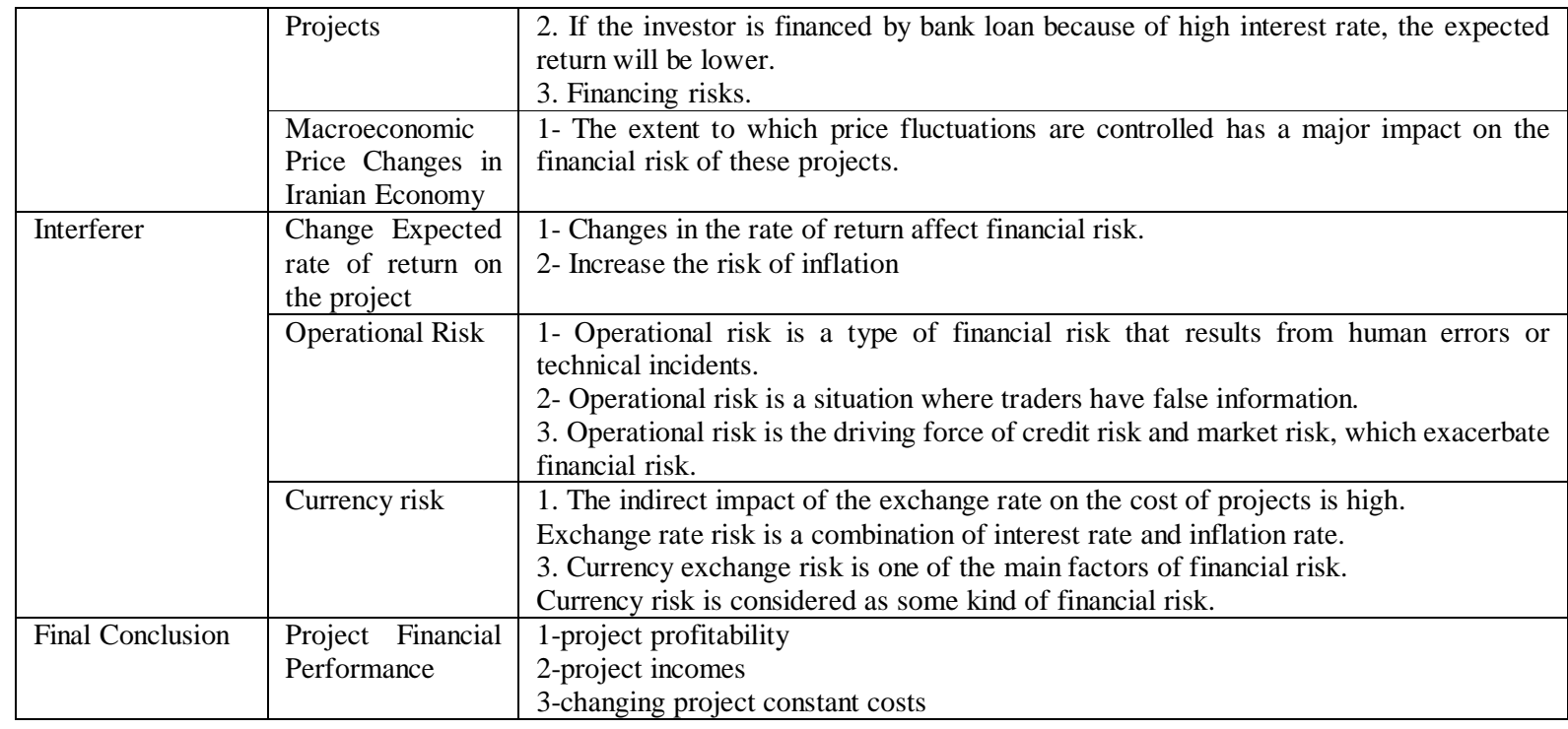

Table 3. Carried Axial Coding in road construction projects of Iran

\subsection{Pivotal Category of Financial Risk of Road Construction Projects in Uncertainty Conditions}

In this study, financial risks in construction projects are considered as a central issue. Because its effects have existed in different parts of the data and plays a central role. Financial risk assessment is subject to three key steps.

The first step is inflation risk, which is considered as the most important financial risk. Inflation risk must be taken seriously by the investors of these projects and is one of the major financial risk assessment issues that are of concern to the entire Iranian industry. So, that this risk can affect the expected rate of return and consequently the financial risk of the road projects. Road construction contractors are undoubtedly at risk and inflationary fluctuations.

The second step in assessing the financial risk of road construction projects is credit risk. Credit risk is one of the most important risk generating factors in banks and financial companies where projects themselves are affected by credit risk. Credit risk is a type of financial risk that is hidden from the perspective of the investors of these projects. Credit risk is in the form of bonds and is based on the fact that the contracting party does not want or cannot fulfil its obligations. Credit risk losses may occur prior to the actual default of the counterparty.

The third step in assessing the financial risk of road construction projects is the interest rate risk. This risk is the root of financial risk and one of the financial risk priorities in road construction projects that leads to inflation and financial risk.

Causal Conditions Causal conditions are a set of events and conditions that affect the central category. The degree of government stability in planning and implementation, the nature of the Iranian capital market, and political risk are three categories that have been identified as causal factors affecting the central phenomenon.

State Stability in Planning and Implementation: State Stability in Planning and Implementation is a causal factor that affects the financial risks of road construction projects in uncertain conditions in Iran. This includes the failure of the government to fulfil its obligations and the wide variety of circulars issued by the Iranian government, affecting the degree of stability of government planning. This is in turn an important factor affecting the financial risks of road construction projects. In addition, the government has an important role to play in project employer repayment, which can be effective in planning and implementing road construction projects.

The nature of the Iranian capital market: One of the causal factors affecting financial risk in Iranian road construction projects is the nature of the Iranian capital market. In this regard, understanding the core nature of the market in terms of investment is the first effective step in this direction. The portfolio should then be selected according to market conditions to offset the loss in one share by another. In addition, any investment project, depending on the type of capital market, is itself a factor in financial risk.

Political Risk: The third causal factor affecting financial risk in Iranian road construction projects is political risk. Political risk is one of the factors that threatens companies and investors in projects and increases financial risk. Political risk itself is not a financial risk, but it can initiate financial risk as it affects interest rates. Political risk has always and always affected interest rates in our country. If we consider political risk as a tree, the interest rate, currency, inflation risks are considered as the foliage of that tree (political risk).

\subsection{Strategies}

Strategies or actions are targeted actions that provide solutions to the phenomenon in question and lead to outcomes and outcomes. Based on the findings and data obtained from the research, a set of differentiation measures and process orientation strategies have been identified as effective strategies in Iranian road construction projects.

1. Bank Financing of Projects: According to the data obtained from this study, bank financing of projects is one of the 
financial risk assessment strategies of road construction projects in Iran. In other words, it is recommended that banks finance these projects in order to reduce the financial risk of these projects. Because if the investor is financed through a bank loan because of high interest rates, the expected return will be lower.

2. Changing macroeconomic prices in the Iranian economy: There is a huge change in macroeconomic prices in the Iranian economy, which in turn increases the financial risk. Therefore, controlling price fluctuations has a major impact on the financial risk of these projects.

Interventional Conditions: A set of events that occur after the study begins and during the research. In the present study, confounding conditions are factors that occur in the process of financial risk assessment of road construction projects. Three categories are considered as interfering conditions in Iranian road construction projects:

Expected Return Rate Changes of the Project: One of the categories of confounding conditions that can cause disruptions is the rate of return that affects the financial risk. It also highlights the project's expected return on inflation.

Operational risk: Another of the intervening factors in financial risk assessment. Operational risk is a type of financial risk that results from human error or technical error. This risk refers to situations where traders have false information. Therefore, operational risk is the driving force behind credit risk and market risk that exacerbate financial risk.

Currency Risk: The third interventionist category can be called exchange rate risk. Currency risk is a combination of interest rate and inflation rate and is one of the main factors of financial risk. The indirect impact of the exchange rate on the cost of the projects is high and is therefore considered as an interventionist.

Ruling Bed: Bed conditions are the set of conditions that provide the context for the phenomenon in question and affect behaviours and actions. The bed conditions affect the axial category and the results. In this study, the categories of liquidity risk and market risk are considered as bed conditions.
Liquidity Risk: If you finance a project in the form of buyer bonds, you will be exposed to liquidity risk. The faster the asset is traded, the lower the risk of liquidity. Investors look at liquidity from the perspective that they can buy and sell assets. Therefore, given the importance of road construction projects if these projects are financed by bond issuance, the liquidity risk in these projects should be doubled and must be taken very seriously.

Market Risk: This risk is the second category that dominates the financing of road construction projects. Investors in road projects face direct market risk. Market risk arises from changes in the price of financial instruments, in other words, direct market risk is caused by changes in stock prices and interest rates that affect the financing of these projects.

Consequences: Consequences are the results obtained from strategies and actions related to the axial category. Consequences of the uncertainty involved in financing the financing of Iranian road construction projects include the financial performance of the project, which primarily results in the project's profitability and profitability and includes project fixed cost changes.

Thus, despite the volatility of government planning and numerous risks including market risk, liquidity risk, interest rate risk, operational risk, inflation and credit risk, macroeconomic price fluctuations control and bank financing Projects can bring the profitability of road projects under conditions of publicprivate partnership.

\subsection{Optional coding}

In selective coding, the main variable or underlying process lies in the data, how, the stages, and the consequences. Based on the relationships obtained, the concepts derived from open and axial coding at the selective coding stage were linked together and reflected as a model in assessing the financing risk of Iranian road construction projects under uncertain conditions (Figure 1).

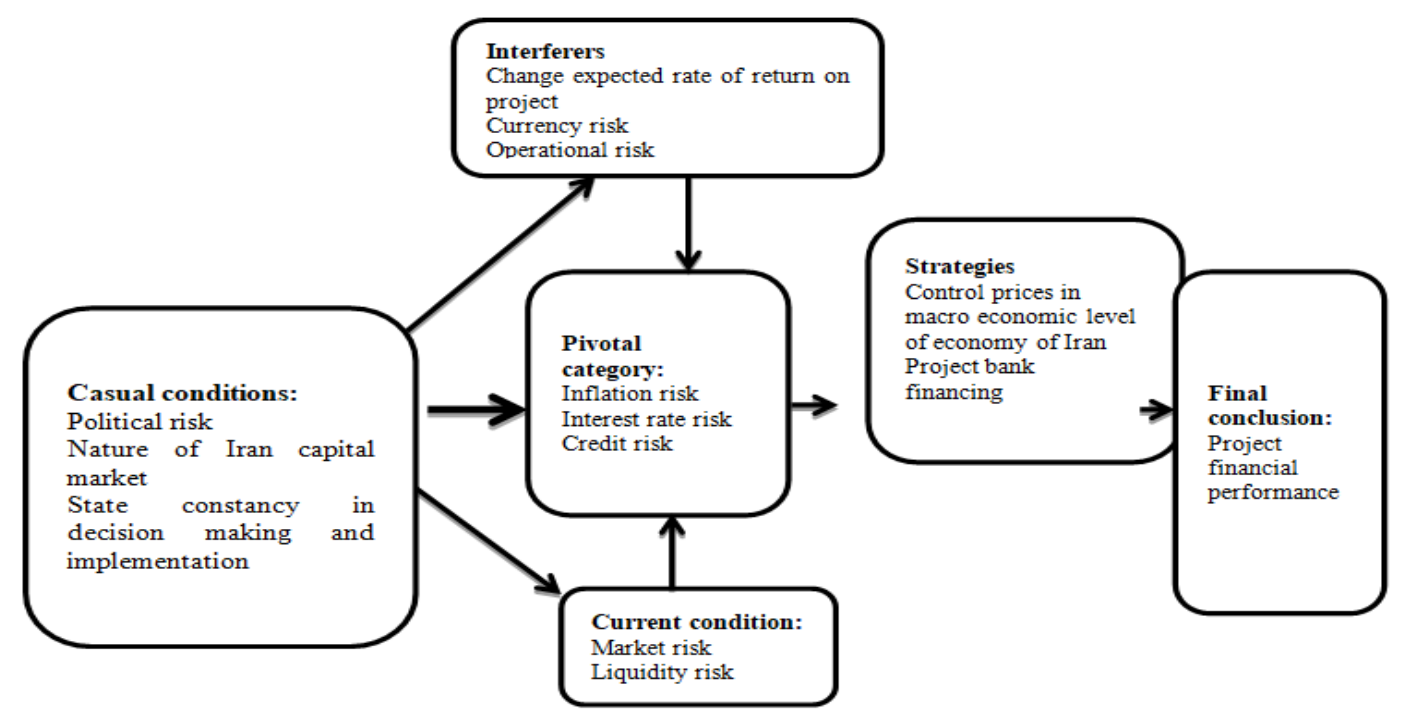

Figure 1. Paradigm of Financial Risk Assessment in Method of Financing Public Private Partnership in Iranian Road Construction Industry 


\section{CONCLUSION \& DISCUSSION}

Regarding the necessity of financial risk assessment in financing "public-private partnership" financing for road construction projects in Iran with uncertainty approach, the present study uses the grounded theory to summarize and examine the categories and components of a comprehensive financial risk model which been involved in these projects.

Previous theoretical literature and previous research, however, have emphasized the conditions of private-public participation and the ranking of financing methods and financial risk management.

According to the research findings, the degree of government stability in planning and implementation, the nature of the Iranian capital market, and political risk are among the risk factors for financing.

While inflation risk, credit risk, and interest rate risk play a vital role in financing, and there are some other factors such as projected rate of return, exchange rate risk, and operational risk arising from human error or technical error and error.

Liquidity risk and market risk also, in turn, increase the risk of financing of construction projects under public-private partnership conditions when project financing is in the form of debt securities and as a result of changes in stock prices and interest rates.

However, controlling macroeconomic price fluctuations in the Iranian economy and financing banks on road projects are among the strategies that, if implemented well, can make road projects profitable despite the existing risks.

\section{References:}

Abadi, M., Behnaba, S. R., \& Akbari, K. (2014). Identifying and Evaluating Critical Risks in HSR Projects through Public-Private Partnerships in Developing Countries. Journal of Structural and Construction Engineering, 1(1), 211-223.

Berezin, A., Sergi, B. S., \& Gorodnova, N. (2018). Efficiency assessment of public-private partnership (PPP) projects: The case of Russia. Sustainability, 10(10), 3713.

Corbin, J., \& Strauss, A. (2014). Basics of qualitative research: Techniques and procedures for developing grounded theory: Sage publications.

Golabchi, M. (2015). Selection of Appropriate PublicPrivate Partnership Approach to Financing Iranian Freeway Projects by AHP Approach, Transportation Engineering. Transportation Engineering, 6(3), 58-69.

Grimsey, D., \& Lewis, M. (2007). Public private partnerships: The worldwide revolution in infrastructure provision and project finance: Edward Elgar Publishing.
Heravi, G. R., \& Alkass, S. (2008, 2008). Risk areas versus critical success factors in public-private partnership construction project agreements.

Heybati, F., Rahnama, R. P. F., Nikoumaram, H., \& Ahmadi, M. (2009). Relationship between economic freedom and public-private partnerships and developing a model for iran. 10(6), 28-35.

Jin, X.-H. (2011). Model for efficient risk allocation in privately financed public infrastructure projects using neuro-fuzzy techniques. Journal of Construction Engineering and Management, 137(11), 1003-1014.

Lawther, W. C. (2005). Public-private partnerships in transportation policy: The case of advanced traveler information systems. International Journal of Public Administration, 28(13-14), 1117-1134.

Linder, S. H. (1999). Coming to terms with the publicprivate partnership: A grammar of multiple meanings. American behavioral scientist, 43(1), 35-51.

Noorzai, E., Jafari, K. G., Golabchi, M., \& Hamedi, S. (2016). Selecting an appropriate finance method of public-private partnership for railway projects in Iran through AHP method. International Journal of Structural and Civil Engineering Research, 5(1), 74-79.

Norouzi, M., Ashari, M. R., \& Beladian, S. M. (2015). Critical Success Factors in Implementing Public-Private Partnership Projects in the Energy Sector of the Islamic Republic of Iran (Case Study: Power Industry). Management Improvement, 29(3), 83-109.

Rasouli, B., Khodiaryar, S., \& Bani Mahd, B. (2018). Identification, Rating and Assignment of Critical Risks of Public-Private Partnership Stages by Delphi Technique in Resistance Economics (Case Study: Guilan Province Water and Wastewater Industry). Investment Knowledge, $7(27), 125-140$.

Sadeghi, S. M., Shahbazi, G. M., \& Bigdeli, V. (2012). Prioritizing the Barriers of Public-Private Partnerships Development in Transportation Sector of Iran Using MCDM Models. 9(11), 125-142.

Salsali, M., Fakhr Movahedi, A., \& Cheraghi, M. A. (2007). Grounded theory research in medical science (Philosophy and Applied Principles). Boshra, Tehran.[Google Scholar].

Savas, E. S., \& Savas, E. S. (2000). Privatization and public-private partnerships.

World, B. (2008). Private participation in infrastructure (PPI) project database. 
Yescombe, E. R. (2011). Public-private partnerships: principles of policy and finance: Elsevier. 